\title{
A MODERNIZAÇÃo DA INSTRUÇÃO PÚBLICA DE MINAS GERAIS A PARTIR DO GRUPO ESCOLAR DR. JOÃO PINHEIRO, NO SERRO/MG (1908-1918)
}

\section{THE MODERNIZATION OF THE PUBLIC INSTRUCTION OF MINAS GERAIS FROM THE GROUP OF SCHOOL DR. JOÃO PINHEIRO, IN SERRO/MG (1908-1918)}

\author{
Danilo Arnaldo Briskievicz
} Instituto Federal de Minas Gerais (IFMG)

\begin{abstract}
RESUMO
Investiga-se o contexto de criação dos grupos escolares em Minas Gerais em seus aspectos legislativos, políticos e sociais. De modo particular, apresenta-se como estudo de caso a inauguração do Grupo Escolar Dr. João Pinheiro e o funcionamento desta escola de instrução pública primária nos seus dez primeiros anos. Explicam-se a modernização e o progresso como ideologias educacionais republicanos e os desafios inerentes à instrução pública, em especial, a pobreza dos meninos e meninas que motivaram a criação da Caixa Escolar. Avalia-se a partir de gráficos estatísticos o cotidiano das matrículas, o cotidiano escolar de alunos e professores, o funcionamento geral da instituição. A metodologia bibliográfica nos levou aos arquivos da escola, aos arquivos da Câmara e aos livros especializados para chegarmos a uma visão geral do contexto estudado. Busca como resultado da pesquisa o detalhamento da instituição e desmascaramento dos conflitos locais que revelam muito sobre o republicanismo brasileiro e suas interfaces com a educação.
\end{abstract}

Palavras-chaves: História da educação. Grupo escolar. Caixa escolar. Instrução pública. Ensino primário.

\section{ABSTRACT}

The context of creation of school groups in Minas Gerais is investigated in its legislative, political and social aspects. In particular, the inauguration of the school Dr. João Pinheiro and the functioning of this primary public education school in its first ten years are presented as a case study. Modernization and progress are explained as republican educational ideologies and the challenges inherent in public education, in particular, the poverty of boys and girls who motivated the creation of Caixa Escolar. Based on statistical graphs, the enrollment routine, the school routine of students and teachers, the general functioning of the institution are evaluated. The bibliographic methodology took us to the school archives, the Chamber (arquivo Brasileiro de Educação, Belo Horizonte, v. 8, n. 17, 2020405 
@rquivo Brasileiro de Educação

Programa de Pós-Graduação em Educação

ISSN: 2318-7344

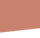

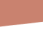

archives and specialized books to arrive at an overview of the studied context. As a result of the research, it seeks to detail the institution and unmask local conflicts that reveal much about Brazilian republicanism and its interfaces with education.

Keywords: History of education. School group. School box. Public education. Primary school. 


\section{INTRODUÇÃO}

Ao final do século XIX, a educação na maioria dos países europeus e nos Estados Unidos da América alcançou a universalização do ensino primário, voltado para crianças da $1^{\mathrm{a}}$ à $4^{\mathrm{a}}$ séries, ou seja, em torno de 7 a 10 anos de idade. No Brasil, a partir de 1890, em São Paulo, uma nova experiência na instrução pública do ensino primário se tornou homogênea e recebeu investimentos da maioria dos estados: os grupos escolares. As antigas escolas isoladas (funcionavam na casa das mestras, dos mestres, com os professores remunerados pelo governo estadual) de método individual cederam lugar para a racionalização e a padronização da escola primária em classes e vários professores com a utilização do método intuitivo ou de ensino popular, ou seja, voltado para as classes populares. A oferta da instrução pública primária foi ampliada e consolidou-se a profissionalização da mulher no magistério. Com isso, o combate ao analfabetismo pela oferta da instrução pública para crianças - meninos e meninas - tornou-se, aos poucos, o centro do discurso de modernização da educação nacional (NAGLE, 2001), baseado na noção do progresso nacional pela expansão da oferta da instrução pública popular e de massa..

Em Minas Gerais, o presidente do estado, o serrano João Pinheiro da Silva (18601908), republicano histórico, percebeu no modelo paulista dos grupos escolares uma forma de modernização da instrução pública que deveria ser levada para todas as cidades mineiras (XAVIER, 1990). Assim, pela Lei ${ }^{\circ}$ 439, de 28 de setembro de 1906, reformou o ensino primário, normal e superior. Destaque para o Art. $1^{\mathrm{o}}$ que determinou a centralidade do governo estadual na reforma ao afirmar que: "fica o Governo de Minas Gerais autorizado a reformar o ensino primário e normal do Estado, de modo que a escola seja um instituto de educação intelectual, moral e física”. No Art. $3^{\circ}$ a nova legislação declarou o seu pressuposto: “o ensino primário, gratuito e obrigatório, será ministrado em: I - Escolas isoladas, II - Grupos escolares, III - Escolas-modelo anexas às escolas normais" (MINAS GERAIS, 1906, p. 20-21).

Comentado [u1]: Prezade, talvez caiba você destacar o que seria esta ideia de modernização, mesmo que de forma concisa, uma vez que você vem retomando essa ideia ao longo do texto.

Comentado [DAB2R1]: Ok

Comentado [u3]: Prezade, talvez caiba destacar que este combate ao analfabetismo ficou mais forte no discurso que na prática, haja visto as desigualdades de acesso e permanência na escolarização.

Comentado [DAB4R3]: Ok 
@rquivo Brasileiro de Educação

Programa de Pós-Graduação em Educação

ISSN: 2318-7344

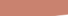

A Lei ${ }^{0} 439 / 1906$ foi complementada com a publicação do Decreto $n^{\circ} 1.947$, do mesmo ano, relativo ao programa do ensino primário e o Decreto no ${ }^{\mathrm{o}}$ 1.969, de 13 de janeiro de 1907, que tratava do regimento interno escolar, inclusive o dos grupos escolares.

Na cidade do Serro, a modernização republicana da instrução pública chegou com a assinatura do Decreto 2.100, no dia 26 de setembro de 1907. Em visita à sua cidade natal, João Pinheiro da Silva criou o Grupo Escolar Dr. João Pinheiro, um dia depois da inauguração oficial das obras da reforma da Casa de Caridade Santa Tereza, o novo hospital da cidade (ARQUIVO PESSOAL MARIA EREMITA DE SOUZA, Caderno 3, n.p.). Para que a reforma do ensino primário serrano tivesse efeito imediato, o presidente da Câmara Municipal e Agente Executivo Municipal Sebastião Augusto de Lima promulgou o Decreto $\mathrm{n}^{0}$ 25, em 31 de março de 1908, alguns meses antes do início do funcionamento oficial do grupo escolar no município sede. Está escrito no Decreto que:

O Presidente da Câmara e Agente Executivo Municipal do Serro dando cumprimento ao que dispõe o artigo $4^{\circ}$ da Lei $n^{\circ}$ 97, de 30 de setembro de 1904 considerando que pelo governo do Estado foi criado um grupo escolar nesta cidade, e considerando que é de maior conveniência a uniformização dos métodos de ensino de acordo com o programa adotado pela última reforma da Instrução primária, decreta:

Artigo $1^{\circ}$ - Fica suprimida a cadeira de instrução primária municipal existente na sede deste município dispensada a respectiva professora e adjunta a quem em nome do município agradeço.

O Grupo Escolar Dr. João Pinheiro da Silva abriu suas matrículas para os $1^{\circ}, 2^{\circ}, 3^{\circ}$ e $4^{\circ}$ anos do ensino primário no dia 04 de maio de 1908 e aceitou que os pais e responsáveis efetivassem o registro de seus futuros alunos e alunas até o dia 27 de maio.

Com a publicação do Decreto $\mathrm{n}^{0} 2.100$ do governo estadual e o Decreto $\mathrm{n}^{0} 25$ do governo municipal serrano, ocorreu a centralização imediata da instrução pública no município sede no Grupo Escolar Dr. João Pinheiro da Silva. Os professores das chamadas escolas isoladas foram demitidos ou reagrupados na nova instituição. As antigas classes que funcionavam nas residências dos professores passaram para o antigo prédio da Escola Normal Municipal do Serro (1895-1903), onde funcionava o governo da cidade.|O impacto da mudança na oferta e funcionamento da instrução pública primária serrana foi gigantesco, pois nunca na cidade tinha havido uma escola com 410 alunos, funcionando @rquivo Brasileiro de Educação, Belo Horizonte, v. 8, n. 17, $2020 \quad 408$

Comentado [u5]: Prezade, sugestão de redação: A Lei ${ }^{\circ}$
$439 / 1906$

Comentado [u17]: Prezade, repetição muito próxima do termo "municipal". Reveja a redação.

Comentado [DAB18R17]: Ok 
@rquivo Brasileiro de Educação

Programa de Pós-Graduação em Educação

ISSN: 2318-7344

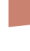

no mesmo edifício, com um grupo tão grande de professores. O contraste com as escolas isoladas era enorme. A modernização da educação pública progressista e desenvolvimentista, parecia, enfim, ter chegado à cidade pelas mãos da elite local, aliada desde 1889, dos ideais republicanos de João Pinheiro, agora imortalizado como patrono do primeiro grupo escolar da cidade.

Portanto, analisar as transformações da instrução pública primária serrana por conta da criação do Grupo Escolar Dr. João Pinheiro é nosso objetivo nesse artigo. Usando os livros do arquivo da instituição sem acesso público a não ser por solicitação direta à instituição - os que sobraram em anos e anos de abandono e desprezo pela história da educação local - pudemos recriar minimamente o cenário dos conflitos sociais em torno da criação do grupo escolar, bem como investigar o cotidiano das atividades docentes e do corpo administrativo. Além disso, podemos levantar hipóteses sobre os resultados práticos dos alunos e alunas a partir da leitura dos diários de classe que resistiram ao tempo e ao descaso e também avaliar qual era a concepção de educação brasileira nesse contexto de 1907 a 1918, a partir do diálogo com outras produções bibliográficas sobre o tema, de outras realidades, de outras localidades, bem como de estudiosos sobre o tema.

\section{O MAGISTÉRIO COMO PROFISSÃO MODERNA}

A proposta do governo municipal serrano de extinguir as escolas isoladas teve um objetivo principal que era ampliar as possibilidades de sucesso do grupo escolar. Havendo apenas uma escola pública gratuita na cidade, as famílias teriam garantido o acesso institucional à instrução de seus filhos. A centralidade da oferta escolar em um edifício único, com um diretor, com apenas um grupo de professores permitiu, também, uma maior fiscalização por parte do Agente Executivo Municipal.

Usou-se a retórica da modernização mais uma vez. Falou-se por todos os cantos que a cidade deveria entrar na onda de progresso iniciada com a república e agora impulsionada pela eleição de um serrano republicano presidente eleito do estado de Minas Gerais, João Pinheiro (BRISKIEVICZ, 2017).

(arquivo Brasileiro de Educação, Belo Horizonte, v. 8, n. 17, 2020 409
Comentado [u19]: Prezade, talvez caiba você colocar alguns dados que forneça um panorama ao leitor sobre a cidade no período retratado.

Comentado [u20]: Prezade, duas questões:
De qual natureza eram estes livros? De matrículas, de
professores, de orçamentos...
Talvez caiba destacar no texto ou em nota de rodapé a
condição de tais arquivos, o acesso dos pesquisadores, a
política ou sua ausência na conservação ou salvaguarda...
Comentado [DAB21R20]: Ok
$\begin{aligned} & \text { Comentado [u22]: Prezade, talvez valha a pena refletir se o } \\ & \text { termo "efetivamente" é cabivel ou adequado na perspectiva } \\ & \text { da história da educação. }\end{aligned}$
Comentado [DAB23R22]: Ok

Comentado [DAB23R22]: $\mathrm{Ok}$

Comentado [u24]: Prezade, repetição do termo "apenas" muito próximo.

Comentado [DAB25R24]: Ok

Comentado [u26]: Prezade, a sua afirmação se assenta em quais fontes ou produções?

Comentado [DAB27R26]: Ok 


\section{merases}

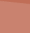

(1)

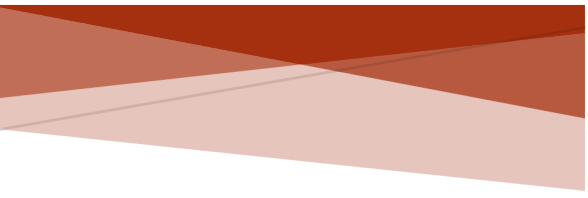

As elites locais viram na inauguração do Grupo Escolar Dr. João Pinheiro a oportunidade de recriar e reapresentar o mito do destino manifesto da antiga Vila do Príncipe como "mater criadora do norte de Minas Gerais" (SILVA, 1914, n.p.). Mito que sempre girou em torno do pretenso destemor de seus primeiros habitantes no século XVIII e do protagonismo político no século XIX. Este mito foi inventado na primeira metade do século XIX na figura do político Teófilo Ottoni (1807-1869) de quem João Pinheiro seria o herdeiro no século XX. Não por acaso, o antigo Largo da Cavalhada havia recebido, logo após a morte de Ottoni, o seu nome. Não por acaso, logo após a morte precoce de João Pinheiro, o antigo largo e a antiga rua se tornou a praça que até os dias atuais leva o seu nome. Inclusive, os bustos de Pinheiro e Ottoni estão imortalizados na mesma praça, de frente para o antigo prédio onde funcionou o Grupo Escolar Dr. João Pinheiro. As elites serranas por diversas vezes, fez questão de assinalar que a cidade do Serro tivera protagonismo na instrução pública brasileira, com escreveu Silva (1914, n.p.):

Foi o município do Serro, em todo o Brasil, o primeiro que, a expensas suas, criou escolas primárias. É tradicional o amor de seus filhos à instrução, Além dos institutos aqui existentes ou que tem existido, os serranos frequentaram, em grande número, colégio e academias de muitas cidades e capitais brasileira, deixando sempre as melhores notas.

Por isso, quando inaugurou-se o Grupo Escolar houve intensa mobilização das elites locais para atualizar o mito do destino manifesto serrano na modernização da instrução pública por seu filho dileto, João Pinheiro. Junte-se a isso uma grande mobilização local em torno da comemoração dos 200 anos de elevação das Minas do Serro do Frio a Vila do Príncipe, acontecida em 1714. Era o momento ideal para recontar o passado e reavivar o mito fundador de uma comunidade progressista e atenta aos sinais do tempo. A campanha republicana e de reforma da educação apareceu nas colunas dos jornais serranos, especialmente $A$ Voz do Serro, no período de 1912 a 1913 mostra em suas páginas (BRISKIEVICZ, 2017).

Quem eram os professores que foram afetados pela extinção das aulas municipais?

Em maio de 1908, quando o Grupo Escolar entrou em funcionamento no prédio do Governo Municipal, os alunos e alunas de todas as escolas públicas perderam suas classes,

Comentado [u28]: Prezade, em alguns lugares você escreve
século por extenso e em outros de forma abreviada. Padronize
essa escrita. Neste caso, ficará a repetição de século bem
próximo.
Comentado [DAB29R28]: Padronizado
$\begin{aligned} & \text { Comentado [u30]: Prezade, tlvez caiba explicar o que seria o } \\ & \text { herdeiro espiritual. }\end{aligned}$
Comentado [DAB31R30]: Ok

Comentado [u32]: Prezade, existiu uma inspiração norteamericana nesta nomenclatura?

Comentado [DAB33R32]: Ok

Comentado [u34]: Prezade, "modernizar" e "modernização" na mesma linha fica um pouco cacofônico, não acha?

Comentado [DAB35R34]: Ok 
remanejadas para a nova escola, com obrigação de matrícula pelos pais ou responsáveis. Havia nesse ano no Serro a primeira e segunda escolas masculinas, a segunda feminina, a primeira possivelmente era o Colégio Nossa Senhora da Conceição, particular, a escolas mistas estadual e municipal. Ao todo, cinco escolas municipais e uma outra estadual. Não há dúvida de que os professores destas escolas isoladas, públicas e mantidas com dinheiro dos cofres do município e do estado, foram aqueles que assumiram algumas classes no novo Grupo Escolar. Para tanto, era necessário passar por um exame de qualificação. As escolas isoladas serranas podem ser identificadas na tabela abaixo que demonstra como cada uma delas contribuiu para o montante inicial de matrículas no novo Grupo Escolar.

Tabela 1 - Contagem de alunos matriculados no Grupo Escolar Dr. João Pinheiro por suas escolas de origem -1908

\begin{tabular}{|c|c|c|}
\hline \multicolumn{3}{|c|}{ Primeira masculina do Serro } \\
\hline Meninos & Meninas & \% no total \\
\hline 50 & 0 & 12,2 \\
\hline \multicolumn{3}{|c|}{ Segunda masculina do Serro } \\
\hline Meninos & Meninas & $\%$ no total \\
\hline 55 & O & 13,4 \\
\hline \multicolumn{3}{|c|}{ Segunda feminina do Serro } \\
\hline Meninos & Meninas & $\%$ no total \\
\hline $\mathrm{O}$ & 64 & 15,6 \\
\hline \multicolumn{3}{|c|}{ Mista estadual do Serro } \\
\hline Meninos & Meninas & $\%$ no total \\
\hline 32 & 14 & 11,3 \\
\hline \multicolumn{3}{|c|}{ Mista municipal do Serro } \\
\hline Meninos & Meninas & $\%$ no total \\
\hline 30 & 25 & 13,4 \\
\hline \multicolumn{3}{|c|}{ Mista particular do Serro } \\
\hline Meninos & Meninas & $\%$ no total \\
\hline 27 & 14 & 10 \\
\hline \multicolumn{3}{|c|}{ Sem anotação de escola anterior } \\
\hline Meninos & Meninas & $\%$ no total \\
\hline 58 & 41 & 24,1 \\
\hline \multicolumn{2}{|c|}{ Total } & $100 \%$ \\
\hline
\end{tabular}

Fonte: Arquivo da E. E. Dr. João Pinheiro, Livro matrícula, 1908-1909.

Caso emblemático foi o da antiga mestra Dona Ana Procópia da Costa. Em 1879, a Câmara Municipal havia decidido criar duas escolas municipais no Quarteirão $\mathrm{n}^{0} 1$ e 8 . O

Comentado [u36]: Prezade, talvez caiba dizer que essa obrigação muitas vezes não se processava na vida real, não é mesmo?

Comentado [DAB37R36]: Eram obrigados por conta de multas.

Comentado [u38]: Prezade, por uma sugestão estética e formal, eu retiraria os colchetes e deixaria a informação entre vírgulas, como um aposto. E também talvez fosse positivo tratar de forma concisa da instituição particular confessional que você cita no texto.

Comentado [DAB39R38]: Não vejo necessidade

Comentado [u40]: Prezade, sugestão de redação: "e as escolas mistas municipal e estadual". Para evitar a repetição de "escola mista".

Comentado [DAB41R40]: Ok

Comentado [u42]: Prezade, repetição das palavras "escola(s)" de forma muito próxima.

Comentado [DAB43R42]: Ok

Comentado [u44]: Prezade, existe informações sobre o exame de qualificação dos professores?

Comentado [DAB45R44]: Eram editais públicos

Comentado [u46]: Prezade, continuação da repetição da palavra "escolas".

Comentado [DAB47R46]: Ok. 
@rquivo Brasileiro de Educação

Programa de Pós-Graduação em Educação

ISSN: 2318-7344

\begin{abstract}
(23)
\end{abstract}
de número 1 era no Gambá, mista; o de número 2, no Pasto do Padilha, para meninos. As escolas ficavam nos extremos da cidade naquela época. A mestra Aninha como era conhecida, era filha de outro professor, Abraão da Costa Veloso (ARQUIVO PESSOAL MARIA EREMITA DE SOUZA, Caderno 139, s.p.), e não conseguiu mostrar-se apta para lecionar no Grupo Escolar no exame obrigatório de qualificação, assumindo o posto de servente para cuidar da limpeza e da refeição dos alunos da mesma escola.

Fato é que os demais professores assumiram suas aulas. O primeiro corpo docente do Grupo Escolar foi composto pelas professoras Ana Gabriela de Almeida e Silva, Christina Amélia de Queirós Queiroga, Virgínia Advíncula Reis, Georgina Otília de Araújo, Rosalina de Almeida e Silva, Maria Mendes de Siqueira Dayrell e os professores Carlos Leopoldo Dayrell Júnior, José Augusto da Paixão e Silva e Francisco da Cunha Pereira. Além disso, havia o porteiro Adrião Pereira de Souza e a servente Ana Procópia da Costa. Com o passar dos anos, alguns professores e professoras tiveram seus substitutos, que ingressaram na escola por nomeação, a fim de cobrir a licença de algum professor titular ou mesmo para assumir seu cargo efetivo: Luiza Victor, Maria Augusta Sampaio, Maria Pastora de Araújo, Amélia de Moura Nunes, Elisa Korsky, Georgina Mourão, Louiza Reis, Carmelita Sampaio, Carlota Amantino, Nelson Araújo Andrada, Augusto Ramos da Silveira e Alarido Dayrell. Estes nomes aparecem nos diários de classe - como titulares ou substitutos - que restaram intactos nos arquivos da escola.

A fim de ilustrar com quantos alunos e alunas os professores lidavam diariamente, relacionamos o número inicial de cada ano no período de 1908 a 1918 a partir dos diários de classe existentes no arquivo da escola. Note-se que, apesar da recomendação de evitarem-se as classes mistas, elas funcionaram até 1917. A entrada de alunos no primeiro ano é normalmente maior que os anos seguintes, mostrando que a reprovação era constante, comum e pelos mais variados motivos como frequência insuficiente, a considerável infantilidade (termo da época para designar defasagem de conteúdos e pouco desenvolvimento físico e psicológico) para seguir para o ano seguinte bem como como a evasão escolar.
Comentado [u48]: Prezade, talvez caiba você problematizar as possíveis razões dessa questão ter acontecido.

Comentado [DAB49R48]: Ok

Comentado [u50]: Prezade, no meu entendimento, se você não tratar de forma particularizada de cada personagem ou evidenciar a importância dos personagens, sugiro que os nomes sejam retirados ou que integrem as notas de rodapé.

Comentado [DAB51R50]: Manter

Comentado [u52]: Prezade, talvez é interessante apontar os motivos da razão de se evitar classes mistas.

Comentado [DAB53R52]: Está na lei de criação do grupo escolar

Comentado [u54]: Prezade, como assim? Infantilidade em qual sentido? Não seria uma defasagem de conteúdos ou uma questão de desenvolvimento físico ou psicológica?

Comentado [DAB55R54]: Ok 
@rquivo Brasileiro de Educação

Programa de Pós-Graduação em Educação

ISSN: 2318-7344

(SS): $2318-734$

\begin{tabular}{|c|c|c|c|c|c|c|c|c|c|c|c|c|}
\hline Sexo & \multicolumn{3}{|c|}{ Masculino } & \multicolumn{5}{c|}{ Feminino } & \multicolumn{5}{c|}{ Misto } \\
\hline Ano & $1^{\mathrm{O}}$ & $2^{\mathrm{O}}$ & $3^{\mathrm{O}}$ & $4^{\mathrm{O}}$ & $1^{\mathrm{O}}$ & $2^{\mathrm{O}}$ & $3^{\mathrm{O}}$ & $4^{\mathrm{o}}$ & $1^{\mathrm{o}}$ & $2^{\mathrm{O}}$ & $3^{\mathrm{O}}$ & $4^{\mathrm{o}}$ \\
\hline 1908 & & 68 & & & & & & & & & & \\
\hline 1909 & 82 & & & & & & & & & & & \\
\hline 1910 & & 56 & & & & & & & & & & 35 \\
\hline 1911 & & 51 & & & & & & & & & & 18 \\
\hline 1912 & & 43 & & & & & & 9 & & & & \\
\hline 1913 & & 35 & & & & & 18 & & & 35 & & 32 \\
\hline 1914 & 60 & 51 & & & & 44 & & & & 52 & & \\
\hline 1915 & & & & & & 61 & & & & & & 34 \\
\hline 1916 & & & & & & & 28 & & 55 & & & \\
\hline 1917 & & & & & $37^{*}$ & & & 37 & 53 & 44 & & \\
\hline 1918 & & 34 & & & & & & & & & & \\
\hline
\end{tabular}

${ }^{*} 2^{\text {a }}$ turma. Fonte: Arquivo da E. E. Dr. João Pinheiro, Pontos diários das aulas, 1908-1918.

Quais as principais atividades dos professores do Grupo Escolar, além da regência das aulas nas suas classes? Segundo Oliveira (2013, n.p.), "de acordo com as normas estabelecidas, cabia ao professor fazer um inventário do mobiliário, dos utensílios e das obras literárias assinado pelo Inspetor"; era obrigado a "verificar os livros de matrícula e de frequência dos alunos, para acompanhamento, caso ocorresse infrequência de um aluno por mais de um mês, isto deveria ser comunicado ao inspetor"; deveria, também, "desempenhar a parte administrativa do ensino, fazendo a escrituração dos livros, mapas com boletins e, também, acompanhar as visitas de autoridades ao grupo escolar".

Para ilustrar a obrigatoriedade do inventário dos bens do Grupo Escolar recorremos ao livro respectivo. Nele estão relacionados o inventário geral do mobiliário, utensílios e material escolar. Segundo suas primeiras anotações, a Secretaria do Interior enviou para a nova escola 130 carteiras americanas com os respectivos tinteiros com dois maços de parafusos para fixação das mesmas carteiras no assoalho e que ainda não tinham sido usadas por conta das alterações nas classes de aula; um armário pertencente à Câmara Municipal; dez cadeiras grandes e treze pequenas pertencentes ao tribunal do júri, além de uma mesa grande para o salão da diretoria, tudo emprestado pelo juiz de direito Dr. Antônio Rodrigues Coelho Júnior; nove potes para água nos salões de aulas e na sala da diretoria, com nove canecas de ferro esmaltado; sete manilhas curvas que sobraram da instalação sanitária; uma sineta suspensa à entrada do pavimento superior; canetas pretas, quadro negro pertencente à professora Dona Cristina Amélia de Queiroga, quatro
Comentado [u56]: Prezade, cabe destacar que embora os professores tivessem tais funções, é importante refletir sobre elas, uma vez que já se têm registro na literatura que muitos professores mentiam sobre o registro dos alunos, já que dependiam desse número para a manutenção das cadeiras e das classes. Fora que se pode problematizar o acúmulo de funções que compunham o trabalho docente.

Comentado [DAB57R56]: Não se aplica. 


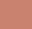

quadros negros vindos das escolas isoladas; um planisfério grande, 12 cartas geográficas murais, um mapa grande do Brasil, um mapa do sistema métrico e um de geometria emprestados pelo presidente da Câmara; e, por último, lousas para alunos pobres, exemplares de hino escolar, modelos de caligrafia americana de letras maiúsculas e minúsculas, 400 cadernos quadriculados, uma bandeira nacional e centenas de livros didáticos para diversas disciplinas (ARQUIVO DA E. E. DR. JOÃO PINHEIRO. Livro Inventário Geral, 1908-1909). Esses são apenas alguns itens do inventário da Grupo Escolar de 1908 que foi sendo atualizado à medida que a escola recebia novos móveis, material didático-pedagógico, material para uso diário da secretaria.

Percebe-se, portanto, que o trabalho individual dos professores em suas próprias casas, lecionando para turmas multisseriadas e multietárias, com grande autonomia decisória sobre a disciplina dos alunos, sobre o conteúdo a ser lecionado e a forma de organizar as turmas sofreu uma alteração radical com a formação do novo Grupo Escolar. Tudo a passa a ser visível para as autoridades que fiscalizam o trabalho docente: a disciplina, a organização dos documentos, a assiduidade. Houve uma regulamentação da atividade docente, bem como a ampliação da fiscalização pelo poder público estadual e municipal daquela que era considera a principal característica do magistério nesse contexto, taxada como principal exigência: a moralidade de quem ensinava.

Em relação à direção do Grupo Escolar Dr. João Pinheiro o primeiro escolhido para o cargo foi o professor Carlos Leopoldo Dayrell Júnior. Filho de Carlos Leopoldo Dayrell e Francisca Joaquina Fernandes de Sampaio. Foi casado com a professora Maria Mendes de Siqueira Dayrell. Faleceu em 1918, logo após graduar-se em Direito. Assumiu a direção do Grupo Escolar em 1908 e aparecia nesta função em $1^{\circ}$ de julho de 1909.

O segundo diretor foi o professor serrano José Augusto da Paixão e Silva (18841947) que apareceu no cargo em documentos oficiais pela primeira vez em janeiro de 1910 e pelo último registro em 1918. Segundo Pires (2015, p. 143), era filho de Raimundo Augusto da Silva e Veridiana Augusta da Silva, devendo "ter estudado com os professores de sua época” pois era "autodidata, demonstrando grande capacidade e interesse pela educação" além de ter sido o fundador da Caixa Escolar "destinada a oferecer material 
escolar e lanche aos alunos carentes". Exerceu o cargo de prefeito nomeado entre os anos 1934-1935. Após sua morte, "em sua homenagem, foi criada a biblioteca 'Professor José Augusto da Paixão', por um grupo de jovens da qual foi escolhido como patrono”.

\section{EXPECTATIVAS EM RELAÇÃO AOS ALUNOS DO GRUPO ESCOLAR}

O Grupo Escolar foi criado para moralizar pedagogicamente crianças e jovens no contexto da Primeira República brasileira. De fato, moralizar significava socializar, ou seja, pretendia-se pela instrução pública primária gratuita e obrigatória modernizar a sociedade brasileira. Nesse projeto, os governos brasileiro, mineiro e serrano estavam unidos a fim de justicarem, inclusive, a república que em seus primeiros anos de funcionamento. Para que serviria ter uma nação republicana, afinal? A instrução pública efetiva, ou que se mostrava na intenção de se tornar transformadora da sociedade, parece ter sido uma boa justificativa para a continuidade do projeto republicano de poder.

Modernizar o Brasil pela educação. Modernizar Minas Gerais pela instrução pública. Modernizar o Serro através de uma instrução primária que atingiria a todos os meninos e meninas do distrito-sede. Um discurso de justificação da república pela educação de seu povo. Assim, caberia uma parceria entre o governo e as famílias para que o progresso social se tornasse realidade. O governo investiria recursos, as famílias matriculariam seus filhos. Um pacto local para um futuro promissor.

Para que as matrículas fossem realizadas, era garantido o direito à educação aos alunos e alunas, segundo o Decreto $\mathrm{n}^{\mathrm{o}}$ 1.960/1906. Contudo, o mesmo decreto no seu Art. 78, exigia que a "criança de idade escolar será de 7 anos para o sexo masculino e de 8 para o feminino; o máximo será de 14 anos para o sexo masculino e de 12 para o feminino" (MINAS GERAIS, 1906, p. 168). A tabela abaixo mostra a participação de cada gênero na matrícula total do novo Grupo escolar.

Tabela 2 - Comparativo entre meninos e meninas matriculados em 1908 e 1909, todas as turmas

\begin{tabular}{|c|c|c|}
\hline & Meninos & Meninas \\
\hline 1908 & 252 & 158 \\
\hline 1909 & 99 & 70 \\
\hline
\end{tabular}

Comentado [u64]: Prezade, pelo sentido não seria mais adequado "intenção"?

Comentado [DAB65R64]: ok

Comentado [u66]: Prezade, eu retiraria os traços e deixaria entre vírgulas, para deixar o texto mais elegante.

Comentado [DAB67R66]: Ok.

Comentado [u68]: Prezade, eu penso que falta uma crítica ao modelo, principalmente no que se refere a sua efetivação e a sua destinação em relação ao público. Pois, fica parecendo que o projeto se efetivou de fato.

Comentado [DAB69R68]: O verbo está no condicional.

Comentado [u70]: Prezade, em alguns lugares você coloca ponto e em outros não. Normalize essa questão do número das leis e dos decretos.

\section{Comentado [DAB71R70]: Ok}

Comentado [u72]: Prezade, e quais eram os possíveis e os sabidos impactos em relação ao estabelecimento de idades mínima e máxima para a escola e para os sujeitos? É possível

que isso tenha fomentado as desigualdades de acesso e de permanência na escola? Apenas uma provocação...

\section{Comentado [DAB73R72]: Ok}

Comentado [u74]: Prezade, não caberia também problematizar as razões variadas do número de meninos matriculados serem superior ao de meninas?

Comentado [DAB75R74]: Não neste artigo. 


\section{@rquivo Brasileiro de Educação}

Programa de Pós-Graduação em Educação

ISSN: 2318-7344

\begin{abstract}
(2)
\end{abstract}
Fonte: Arquivo da E. E. Dr. João Pinheiro, Livro matrícula, 1908-1909.

Por isso, "percebe-se, aqui, que havia uma separação das crianças por idade e sexo” (OLIVEIRA, 2013, n.p.) pois "assim como os funcionários da instituição de ensino tinham deveres a cumprir, o aluno também tinha obrigações” (OLIVEIRA, 2013, n.p.) que eram "chegar no horário das aulas; obedecer ao diretor, aos professores e respeitar os demais funcionários da escola; manter os preceitos de higiene; ser aplicado e ter bom aproveitamento do conteúdo ministrado" (OLIVEIRA, 2013, n.p.); por isso, "em relação às penalidades, o aluno que cometesse alguma falta sofreria punições, obedecendo à seguinte ordem" (OLIVEIRA, 2013, n.p.) seriam aplicadas "advertência; repreensão perante a classe; privação do recreio; e suspensão das aulas por quinze dias” (OLIVEIRA, 2013, n.p.). Nesse sentido, “com o papel de regulador da sociedade republicana, essa escola organizava-se como uma instituição de educação que não ensinava apenas a ler, escrever e adquirir conhecimento de matemática” (OLIVEIRA, 2013, n.p.), mas acabava por contribuir para a concretização de "uma educação voltada para avida social dos indivíduos" (OLIVEIRA, 2013, n.p.) acabando por propor "novos hábitos culturais e morais" (OLIVEIRA, 2013, n.p.). Dessa forma, "o interesse da escola era proporcionar a formação de um novo cidadão, responsável pela nova ordem, capaz de respeitar as normas e colaborar com essa sociedade que emergia, a República” (OLIVEIRA, 2013, n.p.).

As matrículas de alunos e alunas nos anos de 1908 e de 1909 permite-nos tirar algumas conclusões importantes sobre o impacto de uma escola que se pretendia mais impessoal, mais formal e mais burocrática do que as escolas domicialiares/isoladas, centradas na figura do mestre ou mestra. No primeiro ano, as matrículas chegaram a 410 alunos de ambos os sexos nos quatro anos do ensino primário; no segundo ano, devido ao difícil processo de adaptação dos mesmos alunos e da formação do senso comum sobre os caminhos da mesma escola por suas famílias, somado às reprovações no curto ano anterior, iniciado em maio, houve apenas 171 matrículas, com uma redução de $59 \%$.

Tabela 3 - Comparativo de matrículas de alunos e alunas em 04/05/1908 e 07/01/1909

\begin{tabular}{|c|c|c|}
\hline & 1908 & $\mathbf{1 9 0 9}$ \\
\hline $1^{\circ}$ ano & 254 & 70 \\
\hline
\end{tabular}

(arquivo Brasileiro de Educação, Belo Horizonte, v. 8, n. 17, 2020
Comentado [u76]: Prezade, citação superior a três linhas deve vir recuada no texto, seguindo o padrão da ABNT.

\section{Comentado [DAB77R76]: Mudado}

Comentado [u78]: Prezade, fico pensando em duas coisas: Será que nas escolas isoladas tais normatizações e preceitos morais não eram preconizados, mesmo com a pretensa ausência de fiscalização, como você advoga? Outra coisa: falar de imposição de novos hábitos, nega e desconhece um processo de resistência e de saberes outros pré-existentes entre os sujeitos. Eu revia o uso da palavra "impor".

\section{Comentado [DAB79R78]: Mudado}

Comentado [u80]: Prezade, fico pensando se "conclusões" seria a escolha lexical mais adequada para o contexto. E fico imaginando também se a redução do número de matrículas se deveu unicamente a configuração mais impessoal da escola. Penso ser um pouco temerário desconsiderar os contextos sociais de desigualdades diversas de acesso e de permanência na instituição escolar. Fico pensando que você faz pouca ou nenhuma crítica as fontes que, mesmo oficiais, não podem ser tomadas como monumentos, mas sim como documentos passíveis de críticas.

Comentado [DAB81R80]: Ok 
@rquivo Brasileiro de Educação

Programa de Pós-Graduação em Educação

ISSN: 2318-7344

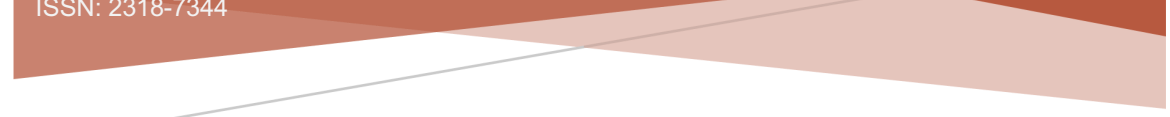

\begin{tabular}{|c|c|c|}
\hline $2^{\circ}$ ano & 89 & 53 \\
\hline $3^{\circ}$ ano & 40 & 24 \\
\hline $4^{\circ}$ ano & 27 & 24 \\
\hline Total & 410 & 171 \\
\hline
\end{tabular}

Fonte: Arquivo da E. E. Dr. João Pinheiro, Livro matrícula, 1908-1909.

A comparação entre matrículas de meninos e meninas no ano de 1908 mostra que o ingresso dos meninos no primeiro ano do ensino primário era da ordem de 7 para 3 meninas. Contudo, esse número praticamente se igualava entre os dois sexos no segundo ano; no terceiro ano, uma leve diferença para maior para as meninas e, no quarto ano, novamente a proporção de meninos era ampliada. Isso mostra que a cidade do Serro com suas escolas isoladas praticamente fazia desaparecer as diferenças de gênero, possibilitando um acesso com certa isonomia à instrução pública.

Tabela 4 - Matrículas de meninos e meninas por ano -1908

\begin{tabular}{|c|c|c|c|c|c|c|}
\hline & Meninas & $\%$ & Meninos & $\%$ & Total & Total \\
\hline $1^{\mathrm{O}}$ & 78 & 30,7 & 176 & 69,3 & 254 & $62 \%$ \\
\hline $2^{\mathrm{O}}$ & 48 & 53,9 & 41 & 46,1 & 89 & $21,7 \%$ \\
\hline $3^{\mathrm{O}}$ & 22 & 55 & 18 & 45 & 40 & $9,7 \%$ \\
\hline $4^{\mathrm{o}}$ & 10 & 37,1 & 17 & 63 & 27 & $6,6 \%$ \\
\hline Total & 158 & 100 & 252 & 100 & 410 & $100 \%$ \\
\hline
\end{tabular}

Fonte: Arquivo da E. E. Dr. João Pinheiro, Livro matrícula, 1908-1909.

No Livro de Matrícula de 1908 é possível identificar a origem social dos alunos e alunas por conta da declaração obrigatória da profissão paterna ou materna. Percebe-se que a diversidade dos diversos estratos das classes sociais serranas. Nesse ponto, parece que o objetivo republicano de estabelecer uma igualdade, pelo menos aparentemente ou apenas formalmente, entre os cidadãos, foi alcançado. A instrução pública nesse contexto parece indicar um aumento do acesso escolar para os mais diversos estratos sociais. É o que nos mostram as próximas tabelas, em que separamos a profissão de quem levou seu filho, filha, tutelado ou tutelada para ser matriculado no Grupo Escolar.

Tabela 5 - Declaração de profissão do pai ou tutor Escola de origem: Primeira masculina do Serro - 1908

\begin{tabular}{|l|c|}
\hline \multicolumn{2}{|c|}{ Mãe } \\
\hline Serviços domésticos & 15 \\
\hline Costureira & 4 \\
\hline
\end{tabular}

Comentado [u82]: Prezade, não seria o grupo escolar? Comentado [DAB83R82]: Não, as isoladas.

Comentado [u84]: Prezade, pela tabela 2, eu penso que as diferenças entre as matrículas por sexo sejam relevantes, não se aproximando muito a uma isonomia. Talvez caiba discutir, tendo em vista as questões sociais e de gênero, os motivos do número de meninos serem maiores no primeiro ano e o de meninas não se igualar ao do sexo masculino, por exemplo.

Comentado [DAB85R84]: Mas trata-se de uma crítica.

Comentado [u86]: Prezade, por mais que o número de meninas fique em algumas ocasiões próximos ou ligeiramente superior ao de meninos, uma diferença diferença de 94 matrículas e com percentuais ora bastante distantes, eu não diria ser isonômico. Penso que, mesmo que a questão de gênero não fosse uma questão planejada na pesquisa, ela emergiu a partir dos dados e ela não pode ser apagada.

Comentado [u87]: Prezade, notei que você usa pouquíssima literatura especializada sobre o período republicano na História da Educação e sobre grupos escolares. É praticamente um ponto pacífico entre os autores que a República não conseguiu nem uma aparente igualdade no acesso a escola e a educação. E aminha interpretação sobre a tabela 5, diverge sobre o que você afirma.

\section{Comentado [DAB88R87]: Ok}

Comentado [u89]: Prezade, pensando a sua tabela 5: a "profissão" da mãe nesse contexto não é tão preponderante, em função da representação da mulher naquela sociedade e isso é demonstrado pela maioria das mães serem donas de casa. Não se trata de menosprezar o serviço doméstico, mas sim, de refletir de forma crítica a questão do gênero naquela sociedade. Agora é preocupante afirmar que a instrução atingiu a maioria dos estratos sociais, quando a grande parte dos pais, em razão de suas profissões, eram profissionais liberais de camadas médias e e funcionários públicos, como o exercício profissional supõe. Pode-se falar em uma diversidade de classes, mas não em um alcance amplo entre elas.

Comentado [DAB90R89]: Ok 


\begin{tabular}{|l|c|}
\hline Professora & 2 \\
\hline Religiosa & 1 \\
\hline Fazendeira Pai & 1 \\
\hline \multicolumn{2}{|c|}{} \\
\hline Negociante & 21 \\
\hline Agências & 14 \\
\hline Empregado público & 8 \\
\hline Lavrador & 4 \\
\hline Ourives & 3 \\
\hline Tabelião & 3 \\
\hline Caixeiro viajante & 2 \\
\hline Pedreiro & 2 \\
\hline Juiz municipal & 2 \\
\hline Advogado & 2 \\
\hline Juiz de direito & 1 \\
\hline Carpinteiro & 1 \\
\hline Operário & 1 \\
\hline Agricultor & 1 \\
\hline Farmacêutico & 1 \\
\hline Tropeiro & 1 \\
\hline Fazendeiro & 1 \\
\hline Falecido & 1 \\
\hline Seleiro & 1 \\
\hline Dentista & 1 \\
\hline Alfaiate & 1 \\
\hline Marceneiro & 1 \\
\hline a) filho(a) matriculado(a) & Fonte. \\
\hline
\end{tabular}

Obs.: há pais/mães com mais de um(a) filho(a) matriculado(a). Fonte: Arquivo da E. E. Dr. João Pinheiro, Livro matrícula, 1908-1909.

Na Tabela 5 sobre as profissões dos pais ou responsáveis dos alunos da primeira escola masculina percebe-se o predomínio entre as mulheres das atividades domésticas, privadas ou mesmo a profissão nominal de costureiras, que remete também à vida privada. Por outro lado, entre os pais, há um predomínio da profissão de negociante, agenciadores e empregados públicos, exercidas no espaço público através de atividades que exigem visibilidade, abertura de lojas ou mesmo a presença diante do público a ser atendido na cidade, em especial na Câmara Municipal do Serro, com sua secretaria e coletoria.

Tabela 6 - Declaração de profissão do pai ou tutor -

Escola de origem: Segunda masculina do Serro- 1908

\begin{tabular}{|l|l|}
\hline \multicolumn{2}{|c|}{ Mãe } \\
\hline Serviços domésticos & 6 \\
\hline Costureira & 3 \\
\hline
\end{tabular}

Comentado [u91]: Prezade, de acordo com a sua leitura, é incoerente afirmar que foi amplo o acesso entreas camadas sociais.

Comentado [DAB92R91]: Ok 


\begin{tabular}{|l|l|}
\hline \multicolumn{2}{|c|}{ Pai } \\
\hline Negociante & 9 \\
\hline Empregado público & 8 \\
\hline Agências & 7 \\
\hline Fazendeiro & 5 \\
\hline Caixeiro viajante & 2 \\
\hline Tropeiro & 2 \\
\hline Ferreiro & 3 \\
\hline Açougueiro & 1 \\
\hline Farmacêutico & 1 \\
\hline Clínico & 1 \\
\hline Pedreiro & 1 \\
\hline Zelador de cemitério & 1 \\
\hline
\end{tabular}

Obs.: há pais/mães com mais de um (a) filho (a) matriculado (a). Fonte: Arquivo da E. E. Dr. João Pinheiro, Livro matrícula, 1908-1909.

Na Tabela 6, da segunda escola masculina do Serro, predomina entre as mulheres as funções da vida privada, ou seja, atividades ligadas ao próprio lar, ou mesmo, atividade informal, como a de costureira. Se comparada com a profissão pública de alfaiate, percebese que se trata de uma atividade ligada à moralidade da época, que pretendia evitar que a mulher se expusesse em público, ou seja, fosse tirar medidas para suas roupas em lojas especializadas. Ao homem não havia esse impedimento moral. Nesse grupo, surge também a figura do caixeiro viajante, um comerciante ambulante, diferente dos tropeiros por viajarem, normalmente sozinhos, enquanto que as tropas de burros eram comitivas.

Tabela 7 - Declaração de profissão do pai ou tutor Escola de origem: Segunda feminina do Serro -1908

\begin{tabular}{|l|l|}
\hline \multicolumn{2}{|c|}{ Mãe } \\
\hline Serviços domésticos & 5 \\
\hline Costureira Pai & 4 \\
\hline \multicolumn{2}{|c|}{} \\
\hline Negociante & 10 \\
\hline Agências & 8 \\
\hline Lavrador & 4 \\
\hline Empregado público & 4 \\
\hline Advogado & 2 \\
\hline Tabelião & 2 \\
\hline Caixeiro & 2 \\
\hline Agricultor & 1 \\
\hline Juiz municipal & 1 \\
\hline Ourives & 1 \\
\hline Operário & 1 \\
\hline Pedreiro & 1 \\
\hline
\end{tabular}

Comentado [u93]: Prezade, o alfaiate não era um "especialista" em "moda" masculina? Será que cabe fazer esse tipo de afirmação?

Comentado [DAB94R93]: É o que está no texto.

Comentado [u95]: Prezade, eu penso que antes de uma questão moral, temos outras questões sociais, anteriores a república que atribuíram papeis distintos a homens e mulheres. Outro ponto que pode inflexionado é da menor diversidade das profissões dos pais nesta segunda escola? Existem dados que podem nos permitir a pensar numa diferenciação socioeconômica entre as escolas?

Comentado [DAB96R95]: Ok. 


\begin{tabular}{|l|l|}
\hline Juiz de direito & $\mathbf{1}$ \\
\hline Carpinteiro & 1 \\
\hline Tropeiro & 1 \\
\hline Fazendeiro & 1 \\
\hline
\end{tabular}

Obs.: há pais/mães com mais de um (a) filho (a) matriculado (a). Fonte: Arquivo da E. E. Dr. João Pinheiro, Livro matrícula, 1908-1909.

Na Tabela 7, da segunda escola feminina serrana, predomina ainda, a referência das mulheres em atividades domésticas e a de negociantes e agenciadores como predominantes. Os funcionários públicos estão ligados às atividades das mais variadas como escriturários no fórum, escrivães de cartórios, secretários da Câmara Municipal e do Agente Executivo Municipal bem como funcionários da Delegacia.

\begin{tabular}{|c|c|}
\hline \multicolumn{2}{|c|}{ Mãe } \\
\hline Serviços domésticos & 5 \\
\hline Costureira & 1 \\
\hline \multicolumn{2}{|c|}{ Pai } \\
\hline Lavrador & 9 \\
\hline Negociante & 7 \\
\hline Empregado público & 3 \\
\hline Sapateiro & 2 \\
\hline Seleiro & 2 \\
\hline Tabelião & 2 \\
\hline Taverneiro & 2 \\
\hline Ourives & 2 \\
\hline Alfaiate & 1 \\
\hline Jornaleiro & 1 \\
\hline Soldado & 1 \\
\hline Ferreiro & 1 \\
\hline Açougueiro & 1 \\
\hline Oficial de justiça & 1 \\
\hline
\end{tabular}

Obs.: há pais/mães com mais de um (a) filho (a) matriculado (a). Fonte: Arquivo da E. E. Dr. João Pinheiro, Livro matrícula, 1908-1909.

Na Tabela 8 da escola mista estadual as mulheres declaram duas atividades domésticas, uma não remunerada e a outra de costureira, de acordo com as demandas locais. Por outro lado, os lavradores aparecem em grande número, não se confundindo com os fazendeiros. Lavrador de pequenas propriedades próximas à cidade, em sua maioria, de subsistência e para pequeno comércio de excedentes. A figura do taverneiro
Comentado [u97]: Prezade, mais uma vez, fica evidenciado por você, que o alcance a diversas camadas não se efetivou. Os dados que você traz estão muito descritivos e pouco analíticos.

Comentado [DAB98R97]: Ok. 


\section{Educação}

(1)

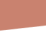

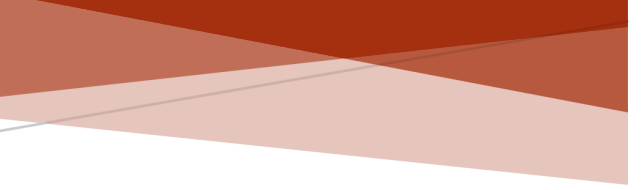

aparece na Tabela 8 podendo ser interpetado como proprietário de pequenas vendas de quinquilharias ou estabelecimento que comercializava bebidas alcóolicas.

Tabela 9- Declaração de profissão do pai ou tutor -
Escola de origem: Mista municipal do Serro - 1908
\begin{tabular}{|l|c|}
\hline \multicolumn{1}{|c|}{ Mãe } \\
\hline Serviços domésticos & 10 \\
\hline Costureira & 3 \\
\hline Professora & 1 \\
\hline \multicolumn{2}{|c|}{ Pai } \\
\hline Agências & 6 \\
\hline Negociante & 3 \\
\hline Lavrador & 3 \\
\hline Operário & 2 \\
\hline Soldado & 2 \\
\hline Pedreiro & 1 \\
\hline Agências & 6 \\
\hline Negociante & 3 \\
\hline Lavrador & 3 \\
\hline Operário & 2 \\
\hline Soldado & 2 \\
\hline Pedreiro & 1 \\
\hline
\end{tabular}

Obs.: há pais/mães com mais de um (a) filho (a) matriculado (a). Fonte: Arquivo da E. E. Dr. João Pinheiro, Livro matrícula, 1908-1909.

Na Tabela 9 da escola mista municipal, ou seja, uma escola mantida somente com os recursos da Municipalidade, aparece a profissão de professora. Trata-se de uma profissão que, de fato, deu certa visibilidade para as mulheres pois não é exercida dentro do lar, na vida privada, mas a docente precisa sair de casa, vestir-se "adequadamente" para a circunstância, precisa transitar pela cidade. Além do respeito social, as professoras eram reconhecidas por romperem com a tradicional perspectiva da vida doméstica, tornandose remunerada por uma atividade pública.

Tabela 10 - Declaração de profissão do pai ou tutor
Escola de origem: Mista particular do Serro - 190
\begin{tabular}{|l|c|}
\hline \multicolumn{2}{|c|}{ Mãe } \\
\hline Serviços domésticos & 1 \\
\hline \multicolumn{2}{|c|}{ Pai } \\
\hline Ourives & 7 \\
\hline Negociante & 6 \\
\hline Sapateiro & 3 \\
\hline Advogado & 3 \\
\hline Agências & 2 \\
\hline
\end{tabular}

Comentado [u99]: Prezade, se existirem fontes, talvez valha
a pena você pensar na existência de um modelo de escola
dualista, em relação a classe social, já que na da tabela oito, o
número de lavradores é ligeiramente superior a de outras
profissões. Cabe talvez também, refletir se ser uma escola
mista, dentro de uma ideia de moralidade da época, fazia
alguma diferença...
Comentado [DAB100R99]: Ok.
Comentado [u101]: Prezade, em uma das primeiras tabelas desta seção apareceu a figura da professora também. Qual a diferença? Talvez, você possa lançar a ideia da sociologia da educação sobre as diferenças na escolarização de filhos de professoras, caso você tenha materiais para isso.

Comentado [DAB102R101]: Ok

Comentado [u103]: Prezade, eu penso que esta análise é desproporcional já que apareceu apenas uma professora e em outro contexto, você não deu relevo para isso.

Comentado [DAB104R103]: Ok 


\begin{tabular}{|l|l|}
\hline Farmacêutico & 2 \\
\hline Fazendeiro & 2 \\
\hline Dentista & 1 \\
\hline Juiz de direito & 1 \\
\hline Jornaleiro & 1 \\
\hline Seleiro & 1 \\
\hline Juiz municipal & 1 \\
\hline Carpinteiro & 1 \\
\hline
\end{tabular}

Obs.: há pais/mães com mais de um (a) filho (a) matriculado (a). Fonte: Arquivo da E. E. Dr. João Pinheiro, Livro matrícula, 1908-1909.

Na Tabela 10 da escola mista particular do Serro predomina a profissão de ourives, uma herança do século XVIII que perdurava na cidade, apesar da pouca atividade mineradora na região. Entende-se que a profissão estava ligada, também, à confecção de alianças de casamento, jóis de família e pequenos consertos de artefatos em ouro. A divisão social do trabalho entre o homens da cidade mostra a quase totalidade de atividades em espaços públicos, em que cabia a negociação com os compradores, Comentado [u105]: Prezade, cabe destacar que neste quadro que se tem o ourives como principal profissão dos pais, a questão da escola ser privada é de algum relevo.

derivando daí a intepretação social de que era uma vida mais dinâmica do que a vida do

Comentado [DAB106R105]: Ok lar.

Tabela 11 - Declaração de profissão do pai ou tutor -

\begin{tabular}{|c|c|}
\hline \multicolumn{2}{|c|}{ Mãe } \\
\hline Serviços domésticos & 11 \\
\hline Costureira & 3 \\
\hline Professora & 2 \\
\hline \multicolumn{2}{|c|}{ Pai } \\
\hline Negociante & 10 \\
\hline Lavrador & 9 \\
\hline Fazendeiro & 6 \\
\hline Empregado público & 4 \\
\hline Agências & 4 \\
\hline Sapateiro & 3 \\
\hline Ourives & 3 \\
\hline Alfaiate & 1 \\
\hline Ferreiro & 1 \\
\hline Farmacêutico & 1 \\
\hline Tabelião & 1 \\
\hline Seleiro & 1 \\
\hline Pedreiro & 1 \\
\hline Juiz municipal & 1 \\
\hline Caixeiro viajante & 1 \\
\hline Carpinteiro & 1 \\
\hline Marceneiro & 1 \\
\hline
\end{tabular}


@rquivo Brasileiro de Educação

Programa de Pós-Graduação em Educação

ISSN: 2318-7344

ISSN: $2318-734400$

\begin{tabular}{|l|l|}
\hline Soldado & 1 \\
\hline Açougueiro & 1 \\
\hline
\end{tabular}

Obs.: há pais/mães com mais de um(a) filho(a) matriculado(a). Fonte: Arquivo da E. E. Dr. João Pinheiro, Livro matrícula, 1908-1909.

Por fim, a Tabela 11 mostra a profissão dos pais e mães de crianças que não frequentavam qualquer escola por ocasião da obrigatoriedade de matrícula no Grupo Escolar. As crianças desse grupo estavam fora de qualquer escola? Não é possível verificar esta informação. Subentende-se, contudo, que não estavam formalmente matriculados em escola do município na data da declaração de matrícula.

A coleta de dados sobre as profissões dos pais dos alunos e alunas serranos por ocasião do fechamento de suas escolas de origem para o agrupamento em apenas uma escola por força de legislação estadual nos permite tirar outras conclusões sobre a republicanização da educação nesse contexto.

Em primeiro lugar, a cidade do Serro se mostra com uma diversidade de profissões dos homens, caracterizando-se por uma vida urbana com crescente classe média com rendimentos médios por conta do comércio, da prestação de serviços especializados e pelo exercício de funções públicas. A atividade urbana crescente é um dos motivos da aceitação da população do projeto dos grupos escolares, com a promessa de progresso e modernização da própria cidade. Segundo Souza (2011, n.p.):

O mecanismo complexo que explica a existência das classes sociais é o segredo mais bem guardado de todas as sociedades modernas. É que o pertencimento de classe define, em grande medida, o acesso privilegiado a qualquer tipo de bem ou recurso escasso. Esses bens e recursos que não precisam ser materiais como um carro ou uma casa, mas também podem ser, por exemplo, o tipo de mulher ou de homem que se consegue ter ou o tipo de reconhecimento social ou prestígio que se desfruta em todas as dimensões da vida. Tudo isso é definido, com alta probabilidade pelo menos e na imensa maioria dos casos, pela herança de classe - pela presença ou ausência relativa de capital cultural e capital econômico - onde se é socializado. O tema da classe desafia, portanto, a ilusão social mais forte entre nós que é a da autonomia ou a liberdade do sujeito individual que é, por sua vez, o fundamento da "meritocracia" moderna, o que Pierre Bourdieu mostrou melhor do que qualquer outro. A classe permite a construção diferencial dos indivíduos pelas heranças típicas de cada classe quebrando a ilusão do "homem universal", como se os pressupostos para a competição social por recursos escassos fossem os mesmos para todos.
Comentado [u107]: Prezade, dois filhos de professoras não estudavam em escola? Não parece interessante para refletir sobre isso?

Comentado [DAB108R107]: Ok

Comentado [u109]: Prezade, eu insisto que a diversidade social das profissões não se processa necessariamente na matrícula dos filhos na escola. Isso deve ser pontuado.

Comentado [DAB110R109]: Ok 
Em segundo lugar, a classe média urbana serrana sabia que uma das formas de acesso às profissões mais bem remuneradas do período era a instrução primária. Por conta dessa instrução, a vocação dos filhos poderia ser testada, enviando-os para outras cidades, a fim de seguirem seus estudos. Um dos passos seguidos por várias famílias serranas para que seus filhos cursassem ensino secundário eram os seminários eclesiásticos, nesse caso, os de Mariana, Diamantina e o Colégio do Caraça. É o que explica Souza (2011, n.p.):

\begin{abstract}
A classe social se forma pela herança afetiva e emocional, passada de pais para filhos no interior dos lares, de modo muitas vezes implícito, não consciente e inarticulado. São esses estímulos que irão construir formas específicas de agir, reagir, refletir, perceber e se comportar no mundo. E é precisamente a presença ou falta de certos estímulos, por exemplo, estímulos para a disciplina, para o autocontrole, para o pensamento prospectivo, para a concentração, que irá definir as classes vencedoras e perdedoras antes mesmo do jogo da competição social se iniciar de forma mais explícita. Existem classes sociais com dificuldades de concentração, por falta de exemplos e estímulos à leitura e a imaginação, que já chegam "derrotadas" na escola e depois, com mais razão ainda, no mercado de trabalho. Existem classes literalmente "sem futuro" porque jamais se pensa nele tamanha a urgência da sobrevivência no presente. Nas classes médias, por exemplo, ao contrário, o futuro é mais importante que o presente o que permite que se tenha futuro. Essa fabricação social de indivíduos com capacidades diferenciais por pertencimento de classe tem que ser cuidadosamente escondida. Daí que se fale apenas no seu "resultado" mais visível, a renda, de modo a que possa se "falar de classe" sem que nada se compreenda de sua dinâmica.
\end{abstract}

Portanto, a origem social dos matriculados do Grupo Escolar mostra uma cidade aberta para a novidade pedagógica republicana. Em tudo, os pais não teriam qualquer coisa a perder colocando seus filhos na nova escola. Era uma troca que se pretendia alcançar certa condição de justiça: o governo fazia o seu papel de modernizar a cidade e as famílias moralizavam seus filhos. Abaixo, resumimos as informações sobre as profissões paternas e maternas.

\section{REPÚBLICA E POBREZA}

A declaração de pobreza dos alunos e alunas no ato da matrícula por seus pais ou responsáveis é um dado que, depois de trabalhado como mostra a Tabela 13, nos permite entender um pouco mais da dinâmica social serrana e suas expectativas em relação à educação. Se por um lado, a classe média sonhava com a carreira estudantil de seus filhos,
Comentado [u111]: Prezade, você realmente considera justo?

Comentado [DAB112R111]: Mudado 


\section{(1)}

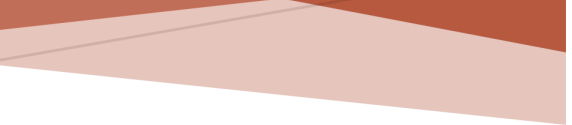

o estrato mais empobrecido da cidade do Serro queria cumprir a legislação para evitar problemas e, ao mesmo tempo, tinha a expectativa de que a escola pudesse ajudar seus filhos de alguma forma. Dessa maneira, a declaração de pobreza é uma forma de precaver a escola sobre a falta de itens básicos como o uniforme escolar ou qualquer roupa que lhe faça as vezes de uniforme, sobre a falta de alimentação adequada em casa ou mesmo sobre a impossibilidade de qualquer contribuição para a escola relacionada a taxas e cobranças. A declaração de pobreza era uma expectativa de ajuda para a família dos alunos e alunas.

Tabela 12 - Declaração de pobreza das famílias a partir das escolas de origem - 1908

\begin{tabular}{|c|c|c|c|c|c|c|}
\hline \multicolumn{7}{|c|}{ Primeira masculina do Serro } \\
\hline \multicolumn{2}{|c|}{ Meninos } & \multicolumn{2}{|c|}{ Meninas } & & \multirow{2}{*}{\multicolumn{2}{|c|}{ Não }} \\
\hline Sim & Não & Sim & Não & Sim & & \\
\hline 27 & 23 & $\mathrm{o}$ & $\mathrm{o}$ & 27 & \multicolumn{2}{|c|}{23} \\
\hline \multicolumn{7}{|c|}{ Segunda masculina do Serro } \\
\hline \multicolumn{2}{|c|}{ Meninos } & \multicolumn{2}{|c|}{ Meninas } & & \multirow{2}{*}{\multicolumn{2}{|c|}{ Não }} \\
\hline Sim & Não & Sim & Não & Sim & & \\
\hline 22 & 33 & 0 & 0 & 22 & \multicolumn{2}{|c|}{33} \\
\hline \multicolumn{7}{|c|}{ Segunda feminina do Serro } \\
\hline & nos & & inas & \multirow{2}{*}{\multicolumn{3}{|c|}{ Total de declarações }} \\
\hline \multicolumn{2}{|c|}{0} & \multicolumn{2}{|c|}{33} & & & \\
\hline Sim & Não & Sim & Não & Sim & \multicolumn{2}{|c|}{ Não } \\
\hline 0 & 0 & 25 & 35 & 25 & \multicolumn{2}{|c|}{35} \\
\hline \multicolumn{7}{|c|}{ Mista estadual do Serro } \\
\hline \multicolumn{2}{|c|}{ Meninos } & \multicolumn{2}{|c|}{ Meninas } & & \multirow{2}{*}{\multicolumn{2}{|c|}{ Não }} \\
\hline Sim & Não & Sim & Não & Sim & & \\
\hline 26 & 6 & 11 & 3 & 37 & \multicolumn{2}{|c|}{9} \\
\hline \multicolumn{7}{|c|}{ Mista municipal do Serro } \\
\hline \multicolumn{2}{|c|}{ Meninos } & \multicolumn{2}{|c|}{ Meninas } & & \multirow{2}{*}{\multicolumn{2}{|c|}{ Não }} \\
\hline Sim & Não & Sim & Não & Sim & & \\
\hline 15 & 15 & 11 & 14 & 26 & \multicolumn{2}{|c|}{29} \\
\hline \multicolumn{7}{|c|}{ Mista particular do Serro } \\
\hline \multicolumn{2}{|c|}{ Meninos } & \multicolumn{2}{|c|}{ Meninas } & & \multirow{2}{*}{\multicolumn{2}{|c|}{ Não }} \\
\hline Sim & Não & Sim & Não & Sim & & \\
\hline 16 & 11 & 5 & 9 & 21 & \multicolumn{2}{|c|}{20} \\
\hline & & Sem & otação & scola & & \\
\hline & nos & & inas & & & \\
\hline Sim & Não & Sim & Não & Sim & & \\
\hline 34 & 28 & 24 & 17 & 58 & & \\
\hline & tal ger & de als & os ma & $\operatorname{ados}$ & $\begin{array}{c}\text { Pobre } \\
\text { Sim }\end{array}$ & $\begin{array}{c}\text { Pobre } \\
\text { Não }\end{array}$ \\
\hline
\end{tabular}

@rquivo Brasileiro de Educação, Belo Horizonte, v. 8, n. 17, 2020

Comentado [u113]: Prezade, nas tabelas supracitadas você demonstra que são poucas matrículas, na maioria das vezes 1 , de filhos de pais de profissões menos prestigiadas, ligados ao trabalho do campo. Nesse sentido, cabe questionar o real cumprimento da parte dos pais em relação a matrícula e a escolarização dos filhos.

Comentado [DAB114R113]: Ok.

Comentado [u115]: Prezade, não só isto. Penso que esta declaração caiba refletir sobre outros aspectos sociais também.

\section{Comentado [DAB116R115]: Ok}

Comentado [u117]: Prezade, talvez caiba mudar na tabela a retirada de meninas quando a escola for masculina e de meninos se a escola for feminina, pois pode dar uma impressão de ausência de carência em algum gênero, quando na verdade, ele não se fazia presente na escola.

Comentado [DAB118R117]: OK 
@rquivo Brasileiro de Educação

Programa de Pós-Graduação em Educação

ISSN: 2318-7344

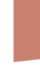
$2318-7344$

\begin{tabular}{|c|c|c|}
\hline 410 & 216 & 194 \\
\hline (\%) & 52,68 & 47,32 \\
\hline
\end{tabular}

A Tabela 13 mostra que dos 410 alunos/alunas matriculados, 52,68\% eram considerados pobres por suas famílias. Considerando a veracidade destes dados, temos que o Grupo Escolar precisaria, também, ser um lugar para a prática da beneficência, do assistencialismo e do paternalismo. Isso explica, por exemplo, a criação e funcionamento da Caixa Escolar Carlos Dayrell Júnior. No período de 19 de agosto de 1916 a 20 de novembro de 1918, o Livro de Ouro funcionou como um mecanismo para angariar fundos para a Caixa Escolar, onde os doadores assinavam o seu nome colocando na mesma linha o valor da contribuição. O Livro de Ouro de 1916-1918 foi aberto com as seguintes palavras:

\begin{abstract}
Aos trinta dias do mês de agosto de 1916, no salão do $4^{\circ}$ ano feminino do Grupo Escolar Dr. João Pinheiro, do Serro, foram pelas alunas do referido ano, eleitas zeladoras do Livro de Ouro para o mês de setembro as quartanistas Maria Augusta de Ávila Reis, Júlia de Azevedo Freire e Ana Lucas da Silva, as quais ficam encarregadas de receber e agradecer, em nome desta diretoria, os donativos que por intermédio do Livro de Ouro foram feitos aos alunos pobres do mencionado Grupo Escolar. Para constar, lavrou-se o presente termo. O diretor do Grupo, José Augusto da Paixão e Silva (ARQUIVO DA E. E. DR. JOÃO PINHEIRO. Livro de Ouro, 1916-1918).
\end{abstract}

Muitas vezes aparece apenas a identificação "um pai de família”, "uma menina”, "um rapaz”, "uma aluna”, "uma senhora”, "um viajante”, "uma devota” ou mesmo "um amigo dos pobres". A abstinência da colocação do nome em sinal de humildade mostra o caráter da beneficência escolar, quase se assemelhando a uma obra de caridade, que segundo os ensinamentos cristãos deveria ser exercida sem alarde, sem notoriedade, sem conhecimento alheio. Por outro lado, o funcionamento da Caixa Escolar evidencia a herança da concentração de renda na cidade do Serro, cuja expressão mais forte foi a perpetuação da pobreza dos egressos da escravidão. Outro grupo que manteve-se na escassez de bens materiais devido as desigualdades econômicas foram os nãoproprietários de terras agricultáveis e mineráveis, concentradas nas mãos de poucas famílias das elites serranas, desde o século XVIII. Formou-se no município, seja no campo

\begin{tabular}{l}
$\begin{array}{l}\text { Comentado [u119]: Prezade, são sabidos os critérios desta } \\
\text { declaração de pobreza entre as famílias? }\end{array}$ \\
$\begin{array}{l}\text { Comentado [DAB120R119]: A oralidade. } \\
\text { Comentado [u121]: Prezade, talvez nem tanto pela condição } \\
\text { social em si do alunado, mas neste período, as ideias de } \\
\text { educação e de assistencialismo, paternalismo se misturam. É } \\
\text { possivel repensar essa afirmação. }\end{array}$ \\
$\begin{array}{l}\text { Comentado [DAB122R121]: Mudado } \\
\text { Comentado [u123]: Prezade, talvez a Caixa escolar seja um } \\
\text { indício não da benevolência em si, mas da ausência do } \\
\text { investimento do Estado e das desigualdades sociais, não? }\end{array}$ \\
Comentado [DAB124R123]: Ok \\
\hline
\end{tabular}

Comentado [u125]: Prezade, você fala a seguir da concentração de renda, mas é importante destacar no sentido da beneficência escolar que a instrução pública, bem como outros direitos sociais, deveriam ser de obrigação pública e não alvo da relação mista entre público e privado, outra marca da época.

Comentado [DAB126R125]: Ok.

Comentado [u127]: Prezade, estas colocações trazidas por você, marcam uma incongruência com outras informações e análises supracitadas, no sentido do acesso, da isonomia e da diversidade entre as camadas sociais na escola.

Comentado [DAB128R127]: OK 


\section{Educação}

\section{.}

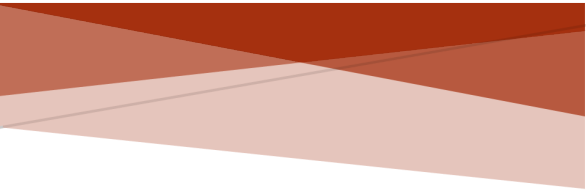

ou na cidade, um enorme grupo de despossuídos constituintes da ralé social: subempregados, desqualificados, explorados pela classe média. Para Souza (2011, n.p.):

\begin{abstract}
A presença de uma "ralé" muito numerosa, que não se confunde com o subproletariado marxista, porque não pode ser utilizada como exército de reserva, devido a não ter as pré-condições para o trabalho técnico no setor competitivo do capitalismo, que se constitui uma classe moderna - pois se forma pela ausência de incorporação dos capitais impessoais, como o capital cultural ou técnico, do mundo moderno -, é o que marca o Brasil como sociedade. Essa classe é explorada pelas classes média e alta como mão de obra barata para todo tipo de serviço pesado e mal pago. Ainda que a "ralé" seja uma classe universal - certamente a mais numerosa do globo -, todos os problemas que ligamos secularmente ao atraso social brasileiro e localizamos falsamente em outros lugares, advém da manutenção indefinida dessa classe de abandonados sociais. Os recentes programas sociais mitigam as formas mais duras da realidade da fome, mas não tocam no principal: possibilitar que a "ralé" deixe de ser "ralé".
\end{abstract}

Nesse sentido, a concentração de renda das elites serranas desde o século XVIII foi um projeto de longo prazo que obteve êxito completo nos primeiros anos da República brasileira. Este projeto de dominação econômica dos meios de produção pode ser evidenciado nos momentos de transição de poder, como por exemplo, no momento da independência nacional e depois na passagem da monarquia para a república. As elites se reorganizavam em torno da manutenção de suas propriedades herdadas da colonização portuguesa. Mudava-se o discurso, mas não a posse das propriedades. Nada mudou estruturalmente na sociedade serrana desde o século XVIII.

A naturalização da propriedade rural, mineira, urbana, comercial por poucas famílias foi tido e havido como fruto da inteligência e superioridade racial das mesmas elites, que vez ou outra, percebendo o agravamento das crises locais, mudavam o discurso dominador para outro, ao estilo, no interior da ideologia republicana, da afirmação de que a modernização da educação criaria outras condições de progresso para todos os serranos, o que de fato não ocorreu. Contudo, a marca inquestionável da acumulação de capital das elites serranas se deu através dos lucros auferidos com escravidão dos africanos e de todas as dinâmicas de mestiçagens que geraram recursos para as mesmas elites locais. A escravidão dos africanos e as suas relações mercantis marcaram definitivamente a história serrana. Por isso, quando o discurso republicano de modernização e progresso pela instrução pública era bafejado na cidade, seus distritos e povoados era como se a
Comentado [u129]: Prezade, esteticamente eu retiraria os traços e colocaria entre vírgulas.

Comentado [u130]: Prezade, o diálogo com Souza é fortuito, entretanto, sinto falta de referências mais implicadas com a História da Educação no período Republicano e com a questão dos grupos escolares.

Comentado [DAB131R130]: Ok

$\begin{aligned} & \text { Comentado [u132]: Prezade, você pode citar até o contexto } \\ & \text { da Primeira República, do poder oligárquico... }\end{aligned}$
$\begin{aligned} & \text { Comentado [DAB133R132]: Ok } \\ & \text { Comentado [u134]: Prezade, talvez caiba pensar em outros } \\ & \text { termos ou melhor explicá-los. }\end{aligned}$
$\begin{aligned} & \text { Comentado [DAB135R134]: Estou me referidno à herança da } \\ & \text { escravidão. }\end{aligned}$
$\begin{aligned} & \text { Comentado [u136]: Prezade, cabe destacar a quem se refere } \\ & \text { estes "todos" na prática vivenciada na república. }\end{aligned}$
Comentado [DAB137R136]: Ok.


@rquivo Brasileiro de Educação

Programa de Pós-Graduação em Educação

ISSN: 2318-7344

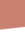

\begin{abstract}
(1)
\end{abstract}

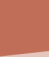

(1)

escravidão tivesse sido coisa de um passado a ser esquecido e reinterpretado como um triste momento da história da cidade e do Brasil. Contudo, a mesma estrutura econômica da cidade herdada com projeto de vida elitista, baseada na acumulação de propriedades em poucas famílias, permaneceu como marca contraditória do discurso republicano.

Aos egressos da escravidão recém emancipados não houve proposta efetiva para a divisão das propriedades rurais, agricultáveis e minerais, bem como das propriedades urbanas, para que pudessem ingressar no mercado de trocas ou para que houvesse algum avanço social de inclusão dessas minorias raciais herdeiras materiais e espirituais da escravidão que os deixou sempre à margem das decisões políticas locais e nacionais. Dessa forma, quando a Caixa Escolar do recém-criado grupo escolar modernizador e progressista republicano anuncia a presença de crianças pobres que necessitam de ajuda para o lanche e para poderem permanecer na mesma escola a pergunta novamente se coloca: não são esses pobres os herdeiros da escassez promovida pela elite serrana em sua acumulação de capital durante os séculos anteriores? Como, de fato, a escola poderia resolver este problema de origem econômica e não pedagógica?

São os dilemas escolares que se reificam na presença dos pobres alunos e alunas serranas. Durante os séculos anteriores, as elites praticaram a caridade para com os mais pobres como forma de garantir um status social de beneméritos reconhecidos pela população local e, ao mesmo tempo, para justificar que a pobreza era uma herança da falta de inteligência ou mesmo falta de civilidade dos escravizados. Contudo, aferradas às suas conquistas patrimoniais, mesmo com a república, continuaram a afirmar, segundo Souza (2015, p. 95), "a violência simbólica da construção do 'merecimento' do privilégio" em que "dentro da tradição religiosa que construiu a moralidade ocidental, são os 'bons' que merecem tudo" e "assim, a violência simbólica bem-feita tem que mostrar que as classes dominantes são, além de mais inteligentes, 'melhores' e mais 'virtuosas'.

A pobreza dos alunos e alunas apareceu em 1909 como uma dívida para a educação brasileira, mineira e serrana. Quem se beneficiou de décadas da escravidão? As elites. Quem lucrou com a escravidão mercantil do tráfico transatlântico? As elites. Quem garantiu seu poder político e econômico com a manutenção de estratos sociais

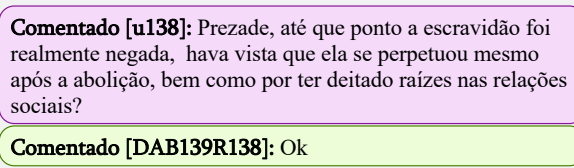

Comentado [u140]: Prezade, retirar o traço e deixar entre vírgulas.

Comentado [DAB141R140]: Ok. Comentado [u142]: Prezade, excelentes perguntas! Cabe
questionar se o ideário do Caixa Escolar não seria mais assistencialista, paliativo que educativo em si?

Comentado [DAB143R142]: Ok. 
@rquivo Brasileiro de Educação

Programa de Pós-Graduação em Educação

ISSN: 2318-7344

ISSN: $2318-7344$

\begin{abstract}
(rõo em
\end{abstract}

\section{Educação}

\section{政}

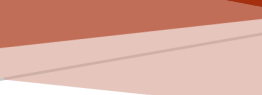

marginalizados nas decisões nacionais?|As elites. Por isso, o conceito de elite serrana pode ser definido por seu viés econômico pois manteve as propriedades como capital e moeda de troca em momentos de transição; pelo viés social por conta dos costumes, valores e ideologias que mantiveram a escravidão e seus lucros como o centro do corpo político serrano, operando no mercado mundial escravista; pelo viés cultural posto que criou manifestações próprias de arte, festas populares, eventos sociais para naturalizar o seu lugar social de prestígio e privilégio; pelo viés religioso cristão em negação das outras religiões de matriz africana e/ou indígena por conta das irmandades católicas que disputaram o prestígio social através da naturalização de suas devoções, festas e rituais. Assim, elite serrana designa um grupo posicionado em local hierárquico nas diferentes instituições sociais públicas, partidos políticos, organizações de classe, concentrando em suas mãos a tomada de decisões políticas, econômicas e educacionais.

A contradição entre o discurso e a realidade da vida cotidiana da maioria da população brasileira quase sempre apareceu na história da educação brasileira, e nesse caso específico na instrução pública serrana, por conta de ser a educação uma moeda de troca para apaziguar os conflitos sociais e amenizar tensões sociais. A inauguração do Grupo Escolar no Serro escancarou, mais uma vez, o uso ideológico da instrução pública como possível transformadora das estruturas sociais herdadas do passado colonialmercantilista-escravista e agora mais uma vez rearticulado em torno do mito da modernização progressista republicana pós-emancipatória.

Portanto, a discussão em torno de um projeto de educação para inclusão social num país marcado pela herança escravista não foi a marca da legislação que criou os Grupos Escolares. A educação em sua instrução pública continuou, mais uma vez, a serviço da naturalização das desigualdades sociais. No caso da cidade do Serro, esse microcosmo brasileiro da dialética entre o passado e o futuro, entre as heranças do colonianismo, da escravidão e sua tentativa de suprassunção pelo progresso e modernização, as elites parecem acreditar em novos tempos sem a revisão do passado, sem as mudanças econômicas para a diminuição das desigualdades sociais.

(arquivo Brasileiro de Educação, Belo Horizonte, v. 8, n. 17, 2020 429
Comentado [u144]: Prezade, substituir o ponto final pelo “?" Comentado [DAB145R144]: Ok.

Comentado [u146]: Prezade, período muito extenso. Eu
retiraria os; e colocaria pontos finais.
Comentado [DAB147R146]: Manter.
$\begin{aligned} & \text { Comentado [u148]: Prezade, você poderia ao longo do texto } \\ & \text { trabalhar e explicitar melhor esta contradição. }\end{aligned}$
Comentado [DAB149R148]: Ok.
Comentado [u150]: Prezade, colocar entre vírgulas.
Comentado [DAB151R150]: Ok.

\begin{tabular}{|c|}
\hline $\begin{array}{l}\text { Comentado [u152]: Prezade, trabalhe com mais afinco nesta } \\
\text { afirmação, para evidenciar que as mudanças foram mais } \\
\text { discursivas que práticas em si. }\end{array}$ \\
\hline Comentado [DAB153R152]: Ok. \\
\hline $\begin{array}{l}\text { Comentado [u154]: Prezade, trazer esta tônica pro início do } \\
\text { texto, corroborando com os seus dados. }\end{array}$ \\
\hline Comentado [DAB155R154]: Ok. \\
\hline $\begin{array}{l}\text { Comentado [u156]: Prezade, se o termo for referente a uma } \\
\text { interação entre tese e antítese a partir da teoria de Hegel, cabe } \\
\text { explicar isso no texto ou em nota de rodapé, para o melhor } \\
\text { entendimento do leitor. }\end{array}$ \\
\hline Comentado [DAB157R156]: O verbo já está bastante em uso. \\
\hline Comentado [u158]: Prezade, substitua os traços por vírgulas. \\
\hline
\end{tabular}

\author{
@rquivo Brasileiro de Educasão, Belo Horizonte, v. 8, n. 17,2020
}


@rquivo Brasileiro de Educação

Programa de Pós-Graduação em Educação

ISSN: 2318-7344

N: $2318-7344$

Isso não quer dizer que a marca dos primeiros anos da república brasileira, em especial da Primeira República (1889-1930), não tenha sido, segundo Nagle (2009, p. 115116), “|inusitado entusiasmo pela escolarização e de marcante otimismo pedagógico: de um lado, existe a crença de que, pela multiplicação das instituições escolares [...] será possível incorporar grandes camadas da população na sendo do progresso nacional",|, por outro, acreditava-se na possibilidade da escolarização que poderia alcançar o ideal da "verdadeira formação do novo homem brasileiro". Assim, a escolarização do Brasil seria o novo "motor da história". A questão social a resolver passaria apenas pela instrução pública ou num conjunto de medidas para o combate das desigualdades sociais? Acreditamos que o primeiro passo é a instrução pública. Os passos seguintes são estruturais. Estariam as elites preparadas para esse enfrentamento?|

\section{CONSIDERAÇÕES FINAIS}

A instrução pública republicana proposta pelo governo do serrano João Pinheiro chegou ao Serro em 1908. Em torno dela reuniu-se a elite local para estimular a representação social de que a educação popular das crianças era uma forma de modernização e de progresso da antiga cidade do Serro. a instrução pública do recémcriado Grupo Escolar Dr. João Pinheiro foi usada como moeda de troca para a manutenção das elites serranas no poder político e na manutenção de seus privilégios econômicos. A educação serviu apenas como um discurso superficial para ocultar, mais uma vez, que as elites permaneceriam com seus privilégios herdados do século XVIII e perpetuados até a Primeira República.

Mostramos como a instrução pública moderna e progressista ampliou o poder local das elites serranas. Uma forma de constatar essa interface da oferta da educação em troca de garantia do poder estabelecido desde sempre é mostrado na imprensa local, em especial, no jornal $A$ Voz do Serro, no período de 1912 a 1913 quando o Grupo Escolar era a principal realização do governo local. Um exemplo pode ser dado a partir da publicação do jornal em 15 de setembro de 1912, relatando como Dr. Félix Generoso tomou posse
Comentado [u160]: Prezade, eu usaria o termo Primeira República, como me parece que você já fez uso antes. Além de padronizar a referenciação, o termo "velha república" marca uma valoração pejorativa proposta pelos ideólogos do regime Varguista, em prol de suscitar uma pretensa distinção entre o "velho" regime e o novo que se iniciara.

Comentado [DAB161R160]: Ok

Comentado [u162]: Prezade, conferir se esta citação não viria recuada no texto.

Comentado [DAB163R162]: Ok

Comentado [u164]: Prezade, retirar o ponto o vírgulo e colocar um ponto final.

Comentado [DAB165R164]: Ok

Comentado [u166]: Prezade, é uma citação do Nagle?

Comentado [DAB167R166]: Ok

Comentado [u168]: Prezade, é uma expressão do Nagle?

Comentado [DAB169R168]: Ok

Comentado [u170]: Prezade, também acredito que deveria ser a instrução pública o início. Entretanto, ela conseguiu ser efetivada? Acho que você mesmo pode responder a sua pergunta sobre a elite e o enfrentamento da desigualdade.

Comentado [DAB171R170]: Ok.

Comentado [u172]: Prezade, esta tônica deve aparecer no início do texto, se não fica com trechos incoerentes.

Comentado [DAB173R172]: OK.

Comentado [u174]: Prezade, em outros momentos, parece que você defende e concorda sem críticas com o modelo de escolarização. Reflita sobre o uso do termo "República Velha".

Comentado [DAB175R174]: Ok.

Comentado [u176]: Prezade, você não faz menção anterior ao jornal. Talvez ele pudesse ser trabalhado ou mencionado para problematizar outras questões. Pois trazer o jornal nas conclusões apenas, não faz muito sentido.

Comentado [DAB177R176]: Incluí acima. 
@rquivo Brasileiro de Educação

Programa de Pós-Graduação em Educação

ISSN: 2318-7344

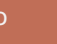

\section{(1)} (1) $\sqrt{2}$

como juiz da Comarca do Serro. Anotando a crônica jornalística, Briskievicz (2017, n.p.), aponta que às $18 \mathrm{~h}$, "grande massa constituída de representantes de todas as classes de nossa sociedade precedida de uma banda de música e ao estrugir de miríades de fogos dirigiu-se à casa do manifestado" e "ali o saudou o inteligente professor José da Paixão, diretor do Grupo Escolar Dr. João Pinheiro. O Dr. Félix convidando a entrarem em sua residência aos amigos soube cumulá-los de gentilezas"; às 2oh, no Grupo Escolar, "os belos salões do grupo escolar admiravelmente ornados e feericamente iluminados abriram-se para receberem ao Dr. Félix e sua exma. família e cavalheiros que incorporados vinham para a soirée dançante última parte das festas ao Dr. Félix" e "dançaram os numerosos convidados e o homenageado animadamente até às $5 \mathrm{~h}$ da manhã”. No dia 22 de julho de 1918, por ocasião do falecimento de José Mórtimer Júnior foram suspensas as aulas do Grupo João Pinheiro e o comércio e oficinas se mantiveram fechadas (BRISKIEVICZ, 2017, n.p.).

Nos dois eventos, o Grupo Escolar estava presente como uma instituição pública, mas controlada pelos políticos serranos. $O$ uso de seu salão para uma festa de aclamação de um juiz de direito da Comarca do Serro mostra as profundas conexões entre os poderes instituídos na cidade. A festa poderia ter sido em qualquer outro espaço público, mas a escolha foi exatamente o Grupo Escolar. No segundo caso, o Grupo Escolar rendeu-se ao costume serrano de respeitar os mortos, especialmente os da elite local, esquecendo-se de que se tratava de uma instituição pública, laica e republicana. O uso da escola como espaço de poder fica esclarecido.

Portanto, o estudo sobre os antecedentes da inauguração do Grupo Escolar Dr. João Pinheiro no Serro em 1908 e a investigação sobre seu funcionamento até 1918 demonstram que a instrução pública republicana teria um grande desafio pela frente, que seja, deixar de ser uma ideologia das elites brasileiras para se tornar uma propulsora das mudanças sociais, principalmente preocupada com a real transformação das desigualdades sociais do passado colonial e monarquista brasileiro.

\section{REFERÊNCIAS}

@rquivo Brasileiro de Educação, Belo Horizonte, v. 8, n. 17, 2020
Comentado [u178]: Prezade, achei os trechos soltos no texto, sem maiores interlocuções e ligações.

Comentado [u179]: Prezade, eu penso que para falar das conexões entre os poderes, você pode tratar de questões já faladas no texto anteriormente, ou trazer o exemplo para outra seção do texto, fazendo na conclusão apenas a retomada e não a apresentação de uma situação nova.

Comentado [DAB180R179]: Ok.
Comentado [u181]: Prezade, trazer esta tônica para o início do texto, para deixar mais coerente.

Comentado [DAB182R181]: Ok.

Comentado [u183]: Prezade, sinto falta de mais referências de estudos da história da educação em Minas Gerais e sobre Grupos Escolares. Parabenizo o usos das fontes primárias, embora pense que você precisa se portar de forma mais crítica a elas.

Comentado [DAB184R183]: Ok. 
ARQUIVO DA E. E. DR. JOÃO PINHEIRO. Livro de ouro, 1916-1918.

ARQUIVO DA E. E. DR. JOÃO PINHEIRO. Livro inventário geral, 1908-1909.

ARQUIVO DA E. E. DR. JOÃO PINHEIRO. Livro matrícula, 1908-1909.

ARQUIVO DA E. E. DR. JOÃO PINHEIRO. Pontos diários das aulas, 1908-1918.

ARQUIVO PESSOAL MARIA EREMITA DE SOUZA. Caderno [3] oo-oo-oooo

Francisco de Assis Gomes Pinheiro [c], sem paginação;

\section{ARQUIVO PESSOAL MARIA EREMITA DE SOUZA. Caderno [139] 25-o6-1987}

Hibisco, sem paginação.

BRISKIEVICZ, Danilo Arnaldo. A arte da crônica e suas anotações: história das Minas do Serro do Frio à atual cidade do Serro em notas cronológicas. (14/03/1702 a 14/03/2003). Porto Alegre: Revolução E-book - Simplíssimo, 2017.

MINAS GERAIS. Lei no 439, de 28 de setembro de 1906. Autoriza o governo a reformar o ensino primário, normal e superior do estado e dá outras providencias. Belo Horizonte: Imprensa Oficial, 1906.

MINAS GERAIS. Decreto no 1.960, de 16 de dezembro de 1906. Aprova o regulamento da instrucção primaria e normal do estado. Belo Horizonte: Imprensa Oficial,1906.

NAGLE, Jorge. Educação e sociedade na primeira república. 3. ed. São Paulo: USP, 2009.

OLIVEIRA, Sandra Maria de. Legislação mineira (1906 a 1924): implantação e criação do grupo escolar. Anais: Semana de História do Pontal, II, 2013, Ituiutaba/MG.

PIRES, Maria de Lourdes Moreira. Valores do Serro. Uma coletânea de perfis serranos. Contagem: s.e., 2015.

SILVA, Alcebíades Nunes de Ávila e. Álbum do Bicentenário 1714-1914. Belo Horizonte: Imprensa Oficial, 1914, s.p.

SOUZA, Jessé. A tolice da inteligência brasileira: ou como o país se deixa manipular pela elite. São Paulo: LeYa, 2015.
Comentado [u185]: Prezade, eu penso que seja melhor separar a referência em duas, mesmo sendo de um mesmo arquivo.

Comentado [u186]: Prezade, favor conferir normas, pois tenho impressão que em referenciação de leis, o dia, o mês e o ano também vão destacados.

Comentado [u187]: Prezade, mesmo comentário que o anterior. 
@rquivo Brasileiro de Educação

Programa de Pós-Graduação em Educação

ISSN: 2318-7344

SOUZA, Jessé. Ralés, batalhadores e uma nova classe média. Entrevista especial com Jessé de Souza. Revista IHU Online, São Leopoldo/RS, 02 fev. 2011, n.p. Disponível em: <http://www.ihu.unisinos.br/entrevistas/40345-rales-batalhadores-e-uma-novaclasse-media-entrevista-especial-com-jesse-de-souza >. Acesso em: 05 jul. 2020.

XAVIER, Maria Elizabeth S. P. Capitalismo e escola no Brasil: a constituição do liberalismo em ideologia educacional e as reformas do ensino (1931-1961). Campinas: Papirus, 1990.

Sobre o autor

\section{Danilo Arnaldo Briskievicz}

Doutor em Educação, mestre em Filosofia, especialista em Temas Filosóficos, licenciado em Filosofia e Pedagogia. Professor de Filosofia e Sociologia do Instituto Federal de Minas Gerais (IFMG). Publicou os livros Poder e violência em Hannah Arendt (2017), A arte da crônica e suas anotações (2017), Comarca do Serro do Frio: história da educação entre os séculos XVIII e XX (2020) e Hannah Arendt: educação e política (2020); organizou O novelo da educação: textos para desatar nós (2019) e, com Rejane Steidel, O novo ensino médio: desafios e perspectivas (2018). Contato: doserro@htmail.com 